\title{
Oral cavity bleeding following snakebite: A case report
}

\author{
Hemorragia em cavidade oral após picada de cobra: Relato de caso \\ Hemorragia oral después de una mordedura de serpiente: Reporte de un caso
}

Received: 12/26/2020 | Reviewed: 12/31/2020 | Accept: 01/01/2021 | Published: 01/04/2021

Mirlany Mendes Maciel Oliveira

ORCID: https://orcid.org/0000-0002-4744-8094 Universidade Federal de Uberlândia, Brazil

E-mail: mirlany.mendess@gmail.com

Lorena Mendes Almeida

ORCID: https://orcid.org/0000-0002-1335-1630 Universidade Federal de Uberlândia, Brazil

E-mail: lorenamalmeida@ outlook.com

Daniela Meneses Santos

ORCID: https://orcid.org/0000-0002-8898-9508 Universidade Federal de Uberlândia, Brazil

E-mail:danyymeneses@yahoo.com.br

Marcelo Caetano Parreira da Silva

ORCID: https://orcid.org/0000-0001-6010-8062

Universidade Federal de Uberlândia, Brazil E- mail: marcelocaetano1@msn.com

Claudia Jordão Silva

ORCID: https://orcid.org/0000-0002-7114-4859

Universidade Federal de Uberlândia, Brazil

E-mail:cjordao1@gmail.com

Darceny Zanetta-Barbosa

ORCID: https://orcid.org/0000-0002-8755-0931

Universidade Federal de Uberlândia, Brazil

E-mail:darcenyzanetta@gmail.com

Jonas Dantas Batista

ORCID: https://orcid.org/0000-0001-5649-6883

Universidade Federal de Uberlândia, Brazil

E-mail: jonasdantasbat@gmail.com

Felipe Gomes Gonçalves Peres Lima

ORCID: https://orcid.org/0000-0001-6385-0465

Universidade Federal de Uberlândia, Brazil E-mail: felipe_peresl@yahoo.com.br

Larissa Gonçalves Cunha Rios

ORCID: https://orcid.org/0000-0002-5385-7150

Universidade Federal de Uberlândia, Brazil E-mail: larissa_cunha@yahoo.com.br

\begin{abstract}
Snakebite is an important public health problem because of its incidence, morbidity, and mortality. It may be related to climatic factors and rural habits. Snakes of the genus Bothrops are responsible for most snakebites in Brazil. The venom of these snakes has peculiar characteristics, with important proteolytic, coagulant, and hemorrhagic actions, leading to local and systemic alterations. Initial manifestations include local tissue injury, pain, swelling, bleeding, and bullous lesions that can progress to abscesses or tissue necrosis. Systemic manifestations should be carefully evaluated especially for the probability of hemorrhagic events such as epistaxis, gingivorrhagia, hematuria, and hemoptysis. Knowing the clinical manifestations of snakebites, as well as the adequate treatment, is essential. Efficient and rapid diagnosis can minimize victims' injuries and the probability of death. The present study reports the clinical case of bleeding at a distant site from the initial site of venom inoculation after bite by a Bothrops snake, emphasizing the therapeutic approach and differential diagnosis in these cases.
\end{abstract}

Keywords: Ophidic Accidents; Complications; Wounds and Injuries.

\section{Resumo}

O acidente ofídico é um importante problema de saúde pública, em virtude de sua incidência, morbidade e mortalidade. Tais acidentes podem estar relacionados à fatores climáticos e hábitos rurais. A serpente do gênero Bothrops é a responsável pela maioria dos acidentes ofídicos ocorridos no Brasil. O veneno desta serpente possui características peculiares, com importantes ações proteolítica, coagulante e hemorrágica, levando a alterações locais e sistêmicas. As manifestações iniciais incluem lesão tecidual local com dor, edema, sangramento e lesões bolhosas que 
podem evoluir para abscessos ou necrose tecidual. Porém, as manifestações sistêmicas devem ser cuidadosamente avaliadas em especial pela probabilidade de eventos hemorrágicos como epistaxe, gengivorragia, hematria e hemoptise. Torna-se imprescindível o conhecimento de manifestações clínicas e abordagem adequada na busca do diagnóstico eficiente e rápido, minimizando assim danos a vítima e a probabilidade de óbito. O presente artigo científico relata o caso clínico de hemorragia a distância do sítio inicial de inoculação da peçonha ocorrido após acidente ofídico com serpente do gênero Bothrops, enfatizando assim a abordagem terapêutica para esses casos além do diagnóstico diferencial neste tipo de ocorrência.

Palavras-chave: Acidente ofidico; Complicações; Ferimentos e lesões.

\section{Resumen}

Los accidents de ofidios son un importante problema de salud pública, por su incidencia, morbilidad y mortalidad. Estos accidents pueden estar relacionados con factores climáticos y habitos rurales. La serpiente del género Bothrops es responsible de la maayoría de las mordeduras de serpientes que ocurrieon en Brasil. El veneno de esta serpiente tiene características peculiares, con importentes acciones proteolíticas, coagulantes y hemorrágicas, que provocam cambios locales y sistémicos. Las manifestaciones iniciales incluyen daño tisular local con dolor, edema, sangrado y lesiones ampollosas que pueden progresar a abscesos o necrosis tisular. Sin embargo, las manifestaciones sistémicas deben evaluarse cuidadosamente, especialmente por la probabilidad de eventos hemorrágicos como epistaxis, gingivorragia, hematia y hemoptysis. El conocimiento de las manifestaciones clínicas y un abordaje adecuado en la búsqueda de un diagnóstico rápido y eficiente es fundamental, minimizando así el daño a la víctima y la probabilidad de muerte. Elpresente artículo científico reporta el caso clínico de hemorragia a distancia del sitio de inoculacion inicial del veneno que ocurrío luego de un de un accidente tipo serpiente conla serpiente Bothrops, enfatizzando así el abordaje terapéutico para estos casos además del diagnóstico diferencial en este tipo de ocurrencia.

Palabras clave: Accidente oicial; Complicaciones; Heridas y traumatismos.

\section{Introduction}

Snakebite is a public health problem because of its morbidity and mortality and high incidence. Injuries by venomous animals have been included in the list of tropical diseases neglected by the World Health Organization (WHO), and it is estimated that there are 1,841,000 cases of envenomation annually worldwide, resulting in 94,000 deaths (Gutiérrez et al, 2019).

Snakebites are related to lifestyle and climate factors, because snakes are ectothermic reptiles. The most common sites of venom inoculation are the lower limbs, especially feet or legs (Albuquerque et al.,2013; Bucaretchi et al., 2001; Costa et al., 2019).

Snakes of the genus Bothrops are responsible for most snakebites, and this higher prevalence may be related to the geographic distribution and aggressive behavior of these snakes (Albuquerque et al., 2013; Costa et al., 2019; Gonçalves et al., 2014; Sgrignolli et al., 2011). Due to the habit of killing the animal by crushing its head after venom inoculation, identification of its genus is difficult, and the treatment is based on the victim's signs and symptoms together with analysis of laboratory tests (Brasil, 2001).

The venom of Bothrops snakes has peculiar characteristics, with significant pathophysiological activities and local tissue injury. Because of its proteolytic action, it can alter the coagulation cascade due to blood incoagulability due to fibrinogen consumption. It can also promote the release of hypotensive substances and trigger capillary basement membrane lesions by the action of hemorrhagins, which together with platelet and coagulation disorders can lead to hemorrhagic manifestations (Bucaretchi et al., 2001; Mise et al., 2018; (Pinho \& Pereira, 2001).).

It is important to know the clinical manifestations of snakebites to classify the injury as quickly as possible and thus initiate treatment, minimizing the probability of morbidity and mortality. Initial clinical manifestations include local tissue injury, pain, swelling, bleeding, and bullous lesions that can progress to abscesses or tissue necrosis. Systemic manifestations may develop clinically as hemorrhagic events such as epistaxis, gingivorrhagia, hematuria, and hemoptysis, among others. In serious cases, severe local and systemic manifestations, severe bleeding, and shock may occur. Thus, attention should be paid 
to signs of severity such as persistent bleeding, neurological symptoms including ptosis, paraesthesia, visual anomalies, and vertigo, cardiovascular abnormalities, and kidney injury (Albuquerque et al.,2013).

Accurate diagnosis and follow-up of clinical evolution should be performed through laboratory tests such as clotting time and partial thromboplastin time, which may be altered. Blood count may present alterations such as leukocytosis with neutrophilia and thrombocytopenia of varying severity. Measurement of serum electrolyte, urea, and creatinine concentrations is also important to previously detect electrolyte imbalance and acute renal failure (Pinho \& Pereira, 2001).

Based on clinical and laboratory alterations, snakebites can be classified as mild, moderate, and severe (Brasil, 2011), shown in Table 1).

For treatment, identification of the animal is essential for intravenous administration of the specific snake antivenom as soon as possible. The inoculation site should be cleaned with soap and water. Elevation of the affected limb slightly above the head may aid in the reduction of swelling. Patient hydration, postural drainage, analgesia, and antibiotic therapy when there is evidence of infection should also be performed (Brasil, 2001) The patient should preferably be hospitalized for at least 72 hours for evaluation (Pinho \& Pereira, 2001).

This scientific article aims to report the clinical case of oral cavity bleeding following bite by a snake of the genus Bothrops, emphasizing the therapeutic approach and differential diagnosis in these cases.

Table 1 - Bothropic snakebites: classification according to severity and recommended serotherapy.

\begin{tabular}{l|l|l|l|}
\hline Manifestations & Mild & Moderate & Intense \\
\hline Places (pain, edema, ecchymosis) & Absent or discrete & Evident & Present \\
\hline $\begin{array}{l}\text { Systemic (Severe bleeding, shock } \\
\text { or anuria) }\end{array}$ & Absent & Absent & \\
\hline Clotting time & Normal or altered & Normal or altered & Normal or altered \\
\hline Serotherapy (No. of ampoules)) & 2 to 4 (intravenous) & 4 to 8 (intravenous) & 12 (intravenous) \\
\cline { 2 - 4 } & & &
\end{tabular}

Source: Brasil (2001).

\section{Methodology}

The present study is a case report, which consists of a type of descriptive, retrospective, qualitative study, done through the technique of direct observation. The patient consisted of disclosing the data and displaying the images by signing a Free and Informed Consent Form (Pereira et al., 2018).

\section{Case Report}

A 13 year-old male patient with leucoderma presented with previous history of snakebite on the anterior surface of the left leg. The patient was first seen at another hospital unit in his city of origin, where he was given snake antivenom and was discharged after 24 hours of observation. After 72 hours of the snakebite, the patient returned to the hospital unit presenting with volumetric increase in the right hemiface, lower lip paresthesia, and absence of pain on palpation. He was seen by the dentistry team, who made an incision in the bottom of the right mandibular vestibule for drainage, as they had as diagnostic hypothesis an abscess of odontogenic origin. Due to the large amount of drained bloody discharge and lack of effectiveness of 
hemostasis maneuvers, the patient was referred to the Oral and Maxillofacial Surgery and Traumatology Service of the Hospital de Clínicas of Uberlândia.

The patient was in good general condition, conscious and oriented, eupneic, and walking. Clinical examination revealed a volumetric increase of soft consistency in the right hemiface, absence of pain on palpation, and active bleeding in the gingival sulcus region of teeth 44,45 , and 46 . Intraoral bleeding was contained by hemostasis maneuvers. To rule out any associated dental focus, a panoramic radiograph was performed, showing the absence of dental involvement justifying the volume increase in the face. Therefore, the diagnostic hypothesis, i.e., an odontogenic abscess, was discarded. Also during physical evaluation, the patient reported having been bitten by a snake 3 days before the beginning of the swelling process. At that time, nonspecific snake antivenom was administered and the patient was hospitalized for 24 hours (Figure 1).

Laboratory tests revealed a significant change in prothrombin time (PT) and an increase in INR (international normalized ratio) (Table 2). Based on the clinical parameters and the patient's history, bleeding at a distant site from the snakebite site was stated as the diagnostic hypothesis, and treatment for the complications of this type of injury was prescribed in collaboration with the general practice team.

Table 2 - Laboratory tests.

\begin{tabular}{|c|c|c|c|}
\hline $\boldsymbol{E X} \boldsymbol{X} \boldsymbol{M}$ & DATE & RESULT & $\begin{array}{c}\text { REFERENC } \\
\text { VALUES }\end{array}$ \\
\hline HEMOGLOBIN & \multirow{7}{*}{$\begin{array}{c}1^{\circ} \text { hospitalization } \\
\text { day }\end{array}$} & 10,1 & $12,8-16$ \\
\hline HEMATOCRIT & & $28,1 \%$ & $37-47 \%$ \\
\hline PLATELETS & & 190,0 MIL & $150-450 \mathrm{MIL}$ \\
\hline$T A P$ & & $33 \%$ & $70-100 \%$ \\
\hline$T T P A$ & & 0,95 & ATE 1,25 \\
\hline$R N I$ & & 2,11 & \\
\hline FIBRINOGEN & & $48,00 \mathrm{mg} / \mathrm{dL}$ & $200-450 \mathrm{mg} / \mathrm{dL}$ \\
\hline HEMOGLOBIN & \multirow{7}{*}{$\begin{array}{c}2^{\circ} \text { hospitalization } \\
\text { day }\end{array}$} & 8,0 & $12,8-16$ \\
\hline HEMATOCRIT & & $22,5 \%$ & $37-47 \%$ \\
\hline PLATELETS & & 170,00 MIL & 150 - 450MIL \\
\hline$T A P$ & & $61 \%$ & $70-100 \%$ \\
\hline$T T P A$ & & 0,87 & ATE 1,25 \\
\hline$R N I$ & & 1,26 & \\
\hline FIBRINOGEN & & $117,00 \mathrm{mg} / \mathrm{dL}$ & $200-450 \mathrm{mg} / \mathrm{dL}$ \\
\hline
\end{tabular}


Research, Society and Development, v. 10, n. 1, e12310111505, 2021

(CC BY 4.0) | ISSN 2525-3409 | DOI: http://dx.doi.org/10.33448/rsd-v10i1.11505

\begin{tabular}{|c|c|c|c|}
\hline HEMOGLOBIN & \multirow{7}{*}{$\begin{array}{c}4^{\circ} \text { hospitalization } \\
\text { day }\end{array}$} & 9,7 & $12,8-16$ \\
\hline HEMATOCRIT & & $26,4 \%$ & $37-47 \%$ \\
\hline PLATELETS & & $256,00 \mathrm{MIL}$ & $150-450 \mathrm{MIL}$ \\
\hline TAP & & $51 \%$ & $70-100 \%$ \\
\hline$T T P A$ & & 25,10 & ATE 1,25 \\
\hline$R N I$ & & 1,39 & \\
\hline FIBRINOGEN & & $71,50 \mathrm{mg} / \mathrm{dL}$ & $200-450 \mathrm{mg} / \mathrm{dL}$ \\
\hline HEMOGLOBIN & \multirow{7}{*}{$\begin{array}{c}5^{\circ} \text { hospitalization } \\
\text { day }\end{array}$} & 9,3 & $12,8-16$ \\
\hline HEMATOCRIT & & $25,5 \%$ & $37-47 \%$ \\
\hline PLATELETS & & 389,0 & $150-450 \mathrm{MIL}$ \\
\hline TAP & & $75 \%$ & $70-100 \%$ \\
\hline$T T P A$ & & $36,00 \mathrm{~s}$ & ATE 1,25 \\
\hline$R N I$ & & 1,17 & \\
\hline FIBRINOGEN & & & $200-450 \mathrm{mg} / \mathrm{dL}$ \\
\hline HEMOGLOBIN & \multirow{7}{*}{$\begin{array}{c}12^{\circ} \text { hospitalization } \\
\text { day }\end{array}$} & 10,4 & $12,8-16$ \\
\hline HEMATOCRIT & & $29,2 \%$ & $37-47 \%$ \\
\hline PLATELETS & & $552,0 \mathrm{mil}$ & $150-450 \mathrm{MIL}$ \\
\hline TAP & & $98 \%$ & $70-100 \%$ \\
\hline TTPA & & 34,20 & ATE 1,25 \\
\hline$R N I$ & & 1.01 & \\
\hline FIBRINOGEN & & $188,00 \mathrm{mg} / \mathrm{dL}$ & $200-450 \mathrm{mg} / \mathrm{dL}$ \\
\hline HEMOGLOBIN & \multirow{2}{*}{$21^{\circ}$ hospitalization } & $12,2 \mathrm{~g} / \mathrm{dL}$ & $12,8-16$ \\
\hline HEMATOCRIT & & $35,5 \%$ & $37-47 \%$ \\
\hline
\end{tabular}




\begin{tabular}{c|c|c|c|}
\hline \multirow{2}{*}{ PLATELETS } & day & $174,0 \mathrm{mil}$ & $150-450 \mathrm{MIL}$ \\
\hline \multirow{2}{*}{ TAP } & \multirow{5}{*}{ TTPA } & $100 \%$ & $70-100 \%$ \\
\hline \multirow{2n}{*}{ RNI } & & & ATE 1,25 \\
\hline \multirow{2}{*}{ FIBRINOGEN } & & 1,00 & \\
\cline { 3 - 4 } & & $234,00 \mathrm{mg} / \mathrm{dL}$ & $200-450 \mathrm{mg} / \mathrm{dL}$ \\
\hline
\end{tabular}

Source: Authors (2020).

Treatment initially consisted of administration of vitamin $\mathrm{K}(10 \mathrm{~mL}$ IV); $800 \mathrm{~mL}$ of fresh frozen plasma and $1000 \mathrm{~mL}$ of cryoprecipitate was further transfused. On the third day of hospitalization, vitamin $\mathrm{K}(10 \mathrm{~mL})$ was administered every 12 hours, and $800 \mathrm{~mL}$ of fresh frozen plasma was transfused again. Due to clinical and laboratory improvements, vitamin $\mathrm{K}$ administration was suspended on the fourth day of hospitalization. Supportive care and strict fluid balance were maintained.

From the fourth day of hospitalization, the ascending swelling of the lower limb slowly started to decrease. The volumetric increase in the face decreased with laboratory improvements. The patient was discharged after 7 days of hospitalization, in good general condition. He still had slight swelling on the face, but it fully disappeared after 15 days of the snakebite. Control laboratory tests were performed 12 days after the snakebite, and laboratory parameters were satisfactory. At 21 days, these parameters were within normal range (Figure 1,2,3,4).

Figure 1 - A / B- 3 days after an ophidian accident.

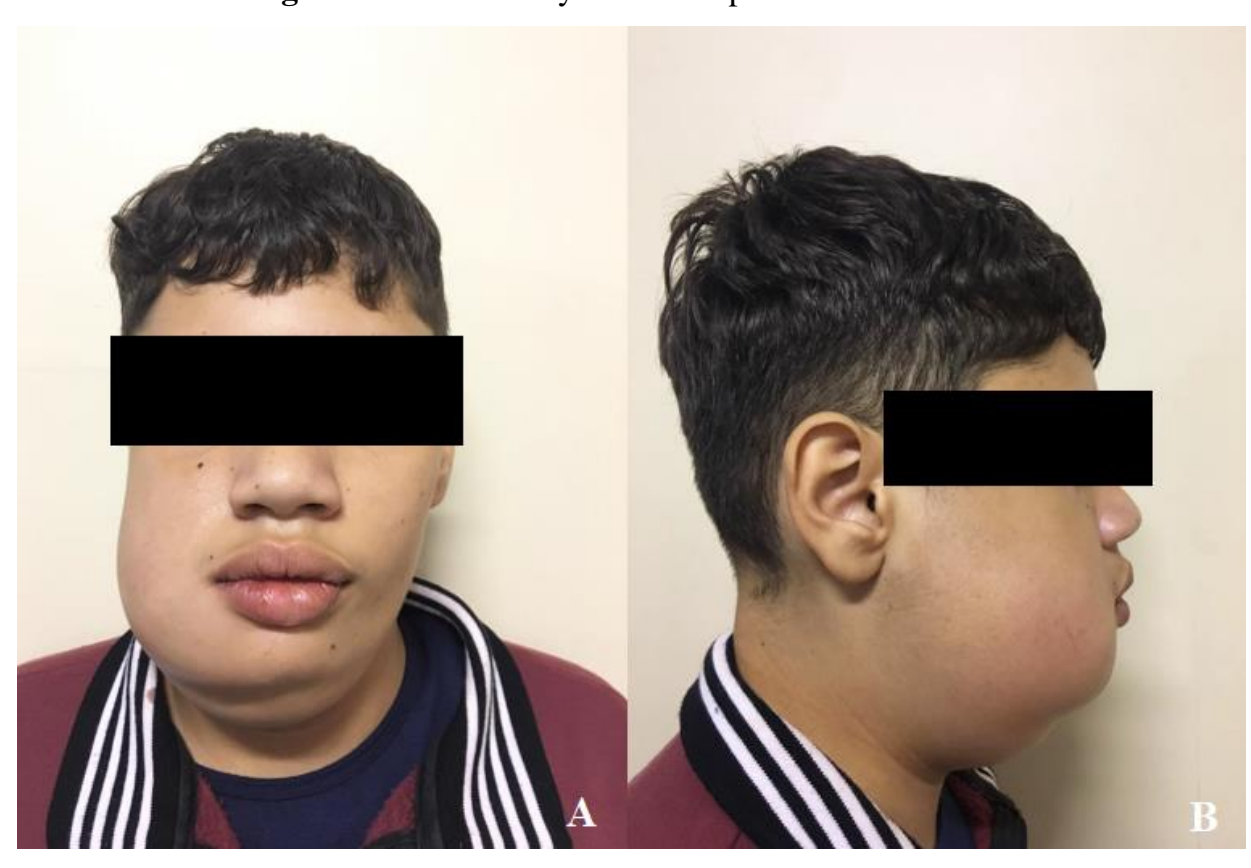

Source: Authors (2020). 
Research, Society and Development, v. 10, n. 1, e12310111505, 2021

(CC BY 4.0) | ISSN 2525-3409 | DOI: http://dx.doi.org/10.33448/rsd-v10i1.11505

Figure 2 - D/C 15 days after official accident.

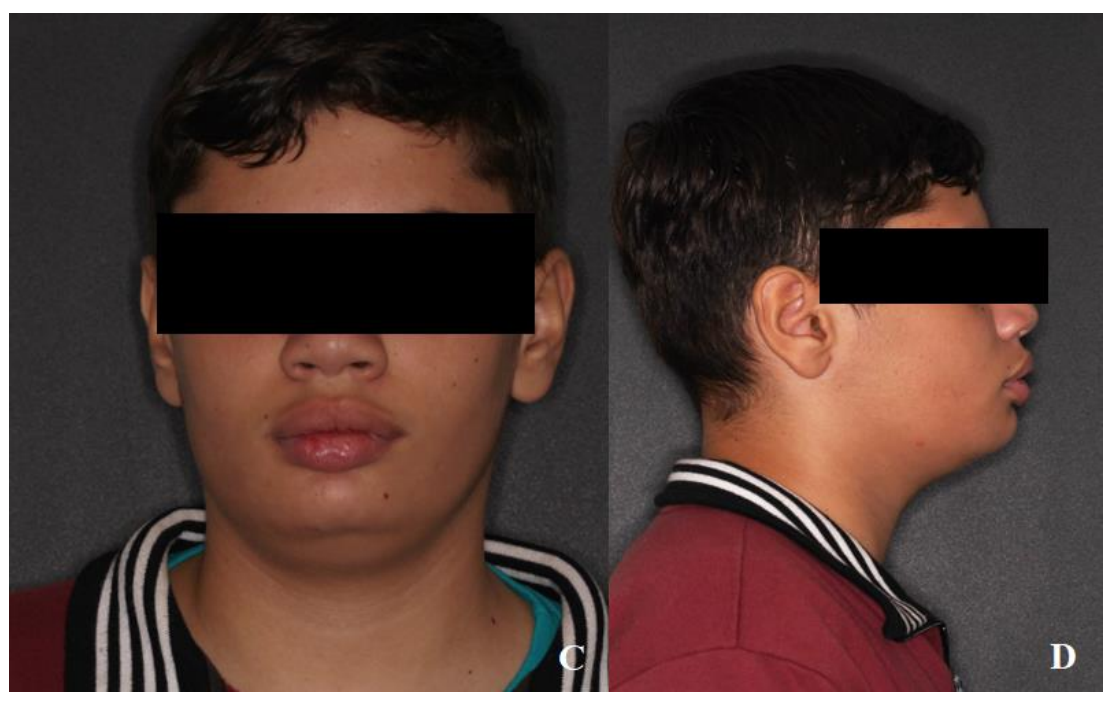

Source: Authors (2020).

Figure 3 - A - Intra-oral appearance in the initial care (3 days after an snakebite); B - Intra-oral appearance 5 days after an ophidian accident.

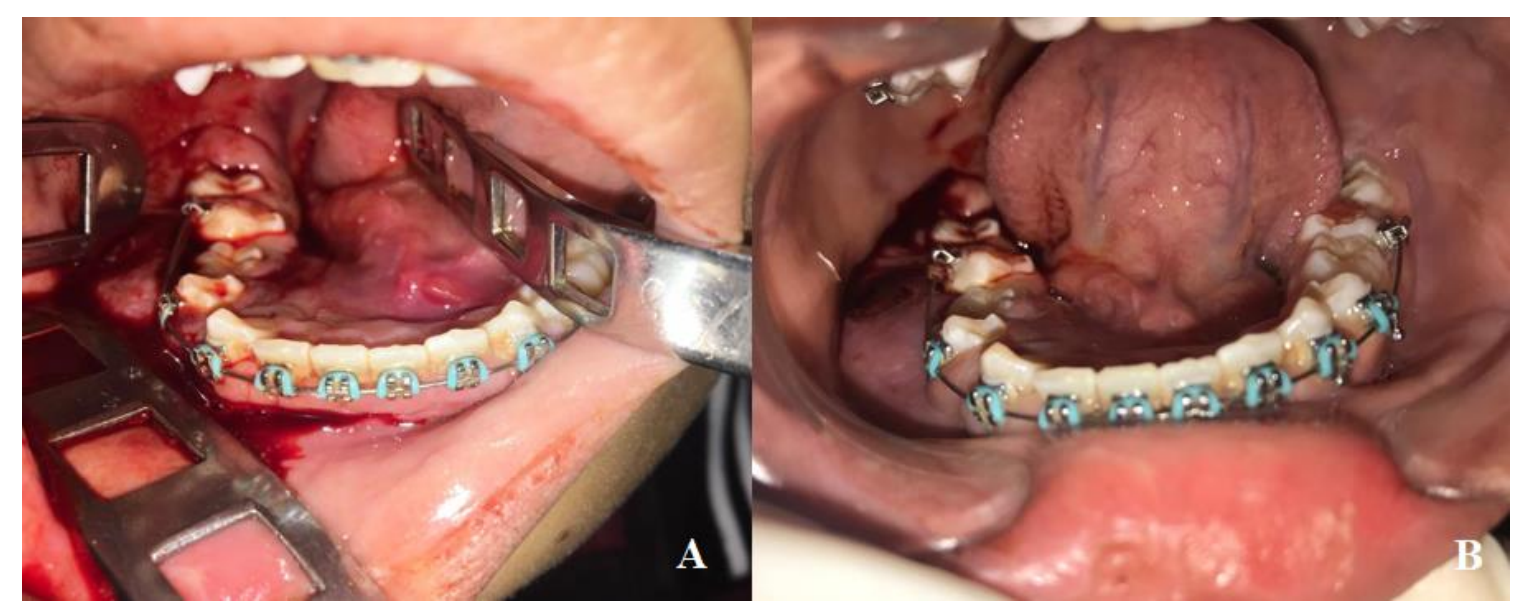

Source: Authors (2020). 
Figure 4 - C- Intra-oral appearance 10 days after an ophidian accident; D - Intra-oral appearance 15 days after an ophidian accident.

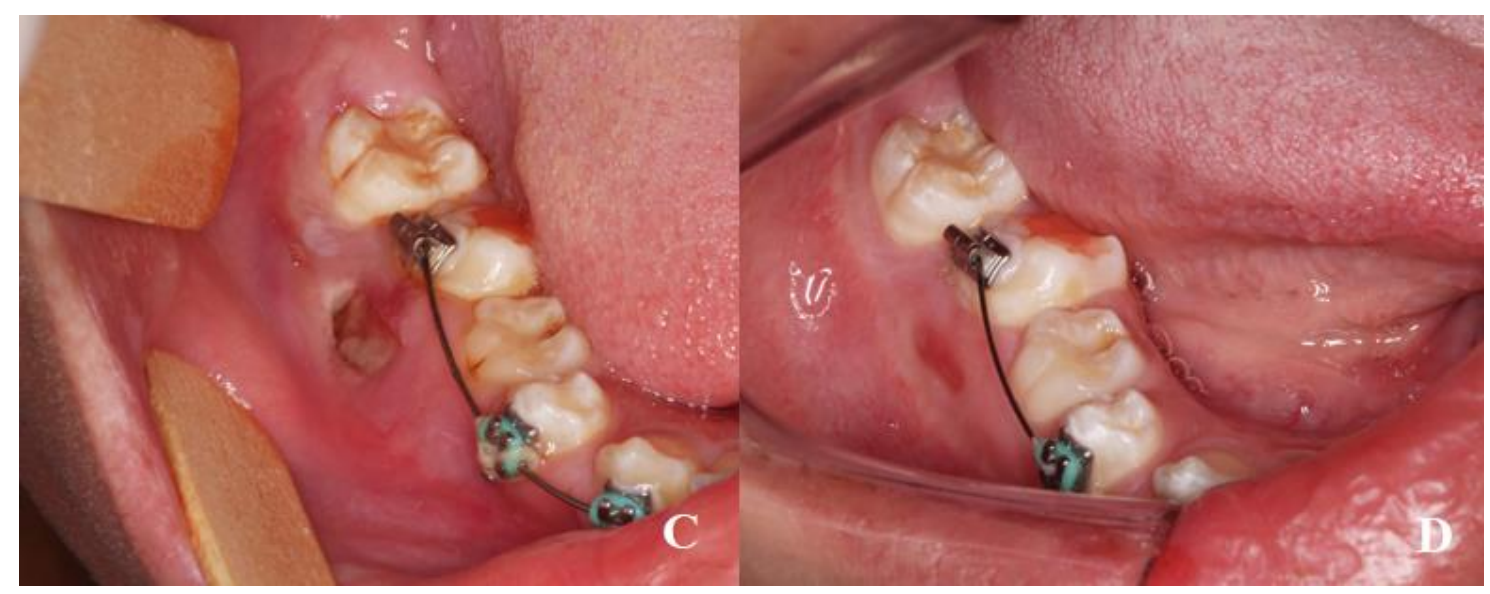

Source: Authors (2020).

\section{Discussion}

We described this case due to the high incidence of snakebites in Brazil. The local and systemic signs presented are compatible with characteristics associated with envenomation by a Bothrops snake (Silva \& Pardal, 2018). Bleeding at a distant site from the snakebite site is predicted in the worldwide literature on snakebites. In cases of misdiagnosis, it can lead to serious consequences due to changes in coagulation factors.

Ribeiro \& Jorge (1997) conducted an epidemiological survey in which they evaluated the blood coagulation parameters of 2,990 patients. One thousand seven hundred and thirty patients $(57.9 \%)$ had blood alterations, corroborating our report, as the patient developed bleeding at a distant site from the snakebite site 72 hours after the snakebite.

The venom of adult Bothrops snakes causes greater tissue destruction, with formation of blisters, abscesses, and necrosis, while that of young snakes causes more blood incoagulability. In this case, it is therefore assumed that the patient was bitten by a young snake, due to the intensity of changes in coagulation factors (Ribeiro \& Jorge, 1997).

Clotting time analysis is important to assess the effectiveness of serotherapy and to determine whether or not to administer additional doses of snake antivenom ${ }^{12}$. According to Pardal \& Gadelhas (2010), coagulation changes normalize less than 24 hours after specific serology at the appropriate dose. However, in this case, a period of hospitalization of approximately 7 days was required for coagulation parameters to be at acceptable rates and not to pose a risk to the victim. Normalization occurred only after 21 days of the snakebite.

As described in the case report, due to the volumetric increase in the face, the dentistry team of the hospital of origin initially had as diagnostic hypothesis an abscess of odontogenic origin. However, only after it was impossible to contain the bleeding and after the referral of the patient to a specialized service, it was possible to make the diagnostic hypothesis of bleeding at a distant site from the snakebite site, based mainly on medical history, clinical examination, and laboratory tests. Therefore, a detailed medical history and a thorough clinical evaluation of the patient are essential points for making the diagnostic hypothesis and initiating effective treatment as soon as possible. Thus, dental surgeons should have basic knowledge of the pathophysiology of snakebites to favor the differential diagnosis and assist in minimizing patient morbidity and mortality in this type of occurrence. 
The case in question can be considered a severe Bothropic snakebite, because, according to Brasil (2001), intense bleeding, regardless of the local manifestations, is characteristic of severe Bothropic snakebites. If the clotting time remains altered within 24 hours of administration of the antivenom, a new dose of the snake antivenom should be administered.

According to Luciano et al. (2009), snake antivenoms, when used properly, are the most effective way to neutralize snake venoms. Therefore, antivenoms should be available in sufficient quantity and in appropriate places, aiming to reduce the time between the injury and proper medical care.

Incorrect classification of the animal can lead to misinterpretation of collected information, thus negatively impacting the health system due to the inappropriate use of public resources and increasing the risk of death of victims due to iatrogenesis (Costa et al., 20019).

Wounds caused by snakebites may get contaminated, and local infectious processes may be associated with bacteria in the animal's mouth or on the victim's skin. The use of tourniquet aggravates the situation. Therefore, antibiotic therapy is recommended when there is evidence of infection (Mise et al., 2018). In the case described here, prophylactic antibiotic therapy was used because the hematoma was a possible contamination site, as it was exposed to the intraoral environment.

Epidemiological studies regarding the incidence of snakebites are essential to optimize victim care, minimize severity, and monitor local needs, having as starting point the implementation of preventive measures and care strategies for this type of occurrence.

\section{Conclusion}

If there is not an adequate initial approach and differential diagnosis, situations like the one described in the present report may evolve negatively. Therefore, knowing the clinical manifestations of snakebites, as well as the appropriate treatment, is essential. Efficient and rapid diagnosis can minimize victims' injuries and decrease the probability of mortality. The planning of preventive and planned treatment measures for these injuries is also essential, in order to minimize the consequences of this type of occurrence for the health of the population. More studies are needed regarding the handling and clinical treatment of claims with snake animals.

\section{References}

Albuquerque, P. L., Jacinto, C., Silva Junior, G. B., Lima, J. B., et al.(2013). Acute kidney injury caused by Crotalus and Bothrops snake venom: a review of epidemiology, clinical manifestations and treatment. Revista do Instituto de Medicina Tropical de São Paulo, 55(5): $295-301$.

Bucaretchi, F., Herrrera, S. R. F., Hyslop, S., Baracat, E. C. E., \& Vieira, R. J. (2001). Snakebites by Bothrops spp in children in Campinas, São Paulo Brazil . Rev. Inst. Med, Trop. 43 (6):329-333.

Costa, M. K. B. D., Fonseca, C. S. D., Navoni, J. A., \& Freire, E. M. X. (2019). Snakebite acidentes in Rio Grande do Norte state, Brazil: Epidemiology, health, managemente and influence of the environmental scenario. Tropical Medicine \& International Heralth. 24(4)432-441.

Gonçalves, R. C., Faleiro, J. H., Lima, G. M., Malafaia, G., et al (2014).The epidemiology of snakebite accidents in the cities of southeast Goiás from 2007 TO 2011. Bioscience Journal. (30)5: 1614-1621.

Gutiérrez, J. M., Theakston, R. D. G., \& Warrell, D. A (2019). Confronting the neglected problem of snake bite envenoming: the need for a global partnership. PLoS Med. 3(6):e150. https:// journals.plos.org/plosmedicine/article?id=10.1371/ journal.pmed.0030150. 10.1371/journal. pmed.0030150.

Luciano, P. M., Silva, G. E. B., \& Azevedo-Marques, M. M. (2009). Acidente botrópico fatal. Medicina 42(1), 61-65.

Machado, C., Bochner, R., \& Fiszon, J. T. (2012). Epidemiological profile of snakebites in Rio de Janeiro, Brazil, 2001-2006. J Venom Anim Toxins incl Trop Dis. 18(2), 217-224.

Ministério da Súde do Brasil. Manual de diagnóstico e tratamento de acidentes por animais peçonhentos. Brasília, 2001.

Mise, Y. F., Lira-Da-Silva, R. M., \& Carvalho, F. M. (2018). Time to treatment and severity of snake envenoming in Brazil. Revista Panamericana de Salud Pública, 42:52.

Pinho, F., \& Pereira, L. (2001) Ofidismo. Revista da Associação Médica Brasileira, 47(1): 24-29. 
Research, Society and Development, v. 10, n. 1, e12310111505, 2021 (CC BY 4.0) | ISSN 2525-3409 | DOI: http://dx.doi.org/10.33448/rsd-v10i1.11505

Ribeiro, L. A., \& Jorge, M. T. (1997). Acidente por serpentes do gênero Bothrops: série de 3.139 casos. Revista da Sociedade Brasileira de Medicina Tropical, 30(6):475-480.

Pardal, P. P. O., \& Gadelha, M. A. C. (2010). Acidentes por animais peçonhentos: manual de rotinas. (2a ed.) SES/PA.

Pereira, A. S., Shitsuka, D. M., Parreira, F. J., Shitsuka, R. (2018). Metodologia em pesquisa científica. UFSM.

Sgrignolli, L., Mendes, G. E. F., Carlos, C. P., \& Burdmann, E. A. (2011). Acute kidney injury caused by Bothrops snake venom. Nephron clinical practice, 119(2):131-137.

Silva, A. M. D., Bernarde, P. S., \& Abreu, L. C. D. (2015). Acidentes com animais peçonhentos no Brasil por sexo e idade. Journal of Human Growth and Development, 25(1)54-62.

Silva, E. O. D., \& Pardal, P. P. D. P. (2018). Envenenamento por serpente Bothrops no município de Afuá, Ilha de Marajó, estado do Pará, Brasil. Revista PanAmazônica de Saúde, 9(3), 57-62. 